\title{
The law and purity in Matthew; Jesus touching a bleeding woman and a dead girl (Mt 9:18-26)
}

NGTT DEEL 55, NO 1, 2014

\section{Viljoen, Francois P}

Faculty of Theology

North-West University (Potchefstroom)

\section{ABSTRACT}

This article investigates the double story in Matthew of Jesus touching a woman with blood flow and a dead girl, with specific reference to purity regulations of the Hebrew Bible. According to Matthew it seems that Jesus did not perform any purity rituals after touching the impure woman and girl. Such negligence would have caused serious repercussions amongst the spectators. In the Sermon on the Mount Jesus explicitly states that $\mathrm{He}$ did not come to abolish the Law, but in this double story Jesus apparently abrogates purity regulations. It is suggested that Matthew purposefully describes these events to demonstrate how these Laws found their fulfilment in Jesus. Jesus is depicted as Emmanuel and Saviour. Instead of Him being polluted by touching these persons, Jesus cleanses the impure woman and raises the dead girl to life. As Holy One purity flowed from Him to the defiled persons, so that they could be cleansed without Him being polluted. These acts of Jesus form part of the coming of the Kingdom of heaven. By accepting Jesus as their saviour, the Matthean community shares the benefits of his purifying power. Their purity is no longer dependent on external purity regulations, but on the cleansing power of Jesus, the Holy One. 


\section{INTRODUCTION}

The topic of the law and purity in the first Gospel is complex. It seems that Matthew's Jesus is not concerned about becoming impure or pure again after contracting impurity (Deines, 2008:65). Matthew does not mention any purification rites in connection with Jesus and the disciples, not even before entering the temple. He only describes actions of Jesus that apparently contravene the purity regulations of the Hebrew Bible. While Jesus in the Sermon on the Mount emphatically states that He did not come to abolish the Law (Mt. 5:17-19) (see Viljoen, 2011), that He requires greater righteousness (Mt. 5:20) (see Viljoen, 2013a) and explains the true intention of the Law in six antitheses (Mt. 5:21-47) (see Viljoen, 2013b), one would expect Matthew to show concern for purity regulations as well. However, nothing in this regard is mentioned. It seems as if Matthew and his community developed a different understanding of purity requirements. In the Beatitudes Jesus states that those who are pure in heart are blessed and will see God (Mt. 5:8) (see Viljoen, 2012). Some other passages in Matthew also imply a development in purity interpretation, namely Jesus touching a leper (Mt. 8:1-4) (see Viljoen, 2014a), Jesus responding to Pharisees who question why He eats with tax collectors and sinners (Mt. 9:9-13) (see Viljoen, 2014b) and Jesus responding to the Pharisees and teachers of the law who accuse Jesus' disciples for not washing their hands before they eat (Mt. 15:1-20).

In this article two occasions with purity implications are investigated: Jesus was supposed to avoid or at least purify Himself after contact with a woman with abnormal menstrual discharge (Lev. 25-30), but Matthew's Jesus does not object when such a woman touches Him and no mentioning is made of any purification rites (Mt. 9:20-22); and He had to avoid contact with a dead body (Num. 5:2; 19:1113) or entering the room of a dead person (Num. 19:14), but Jesus enters the room with the dead girl and touches her (Mt. 9:25). In cases where such contact with a dead or haemorrhage person is accidental, performed as deed of compassion or necessary, the Hebrew Bible prescribes that the defiled person has to undergo specific purification rites (Num. 19). The neglect of such purification rites was regarded as prohibited impurity and reason to be cut off from the community (Num. 19:13, 20). Matthew, however, makes no mention of Jesus undergoing such purification rites. Considering that Matthew's readers, other than those of Mark and Luke, were mostly Jewish Christians, hearing about such seeming negligence from Jesus, would have been noted as cause for concern. Though Jesus emphasises that He did not come to abolish the Law (Mt. 5:17-19), He clearly demonstrates an alternative interpretation of the purity Law.

The intention of this article is to establish the relation between Matthew's Jesus and the purity Laws as demonstrated by these two stories. To do this, the applicable 
Jewish purity regulations will first be investigated and then be compared with Jesus' actions when healing the bleeding woman and dead girl. From this comparison, certain conclusions will be drawn.

\section{PURITY REGULATIONS REGARDING DEATH AND MENSTRUAL BLEEDING}

Purity or the lack thereof plays a fundamental role in Ancient Israel's religion. According to the laws of Exodus, Leviticus and Numbers purity or impurity refers to a state of physical and spiritual purity or impurity that permitted or prohibited access to God. Cultic purity implies moral purity. It has its roots in the command: "Be holy, because I, the Lord your God, am holy" (Lev. 19:2) (Vriezen \& van der Woude, 2005:244).

Similar references to purity are found in later writings of the Hebrew Bible, such as the Psalms and the Prophets. Purity is demanded by the "Holy One of Israel" (Is. 1:4; 5:19,24). God is the ideal manifestation and source of holiness (Chilton, 2000:877). Only the one, who has clean hands and a pure heart, may ascend the mountain of the Lord and stand in his holy place (Ps 24:3-4) (cf. Pss. 18:21; 24:3-6; 26:4-7; 51:4, $8,9,12 ; 119: 9)$.

Some impurities are avoidable, and are prohibited under all circumstances. Prohibited impurities result from contamination that could have been avoided or as a result of mismanagement of unavoidable impurities or from the violation of moral norms. Others are unavoidable as they come about as the result of natural circumstances, e.g. death, sexual relations, disease, etc. However, for such unavoidable impurities specific methods of purification are prescribed, like washing, sacrifices, disposal or required time lapses (Wright, 1992:736-737). Among all these laws prescribed for different situations, the purity laws related to death and sexual discharge are applicable to the stories of Mt. 9:18-26.

\subsection{Purity regulations related to death}

Touching a human corpse is regarded as the most serious of permitted impurities. A person becomes impure (tame') through contact with a "dead body", which includes significant parts of a body or the soil in which the body has decomposed, or by being present in a building or roofed structure containing a dead body: ${ }^{1}$

1 One can become impure by contact with a primary source of impurity or an object that has been in contact with a primary source of impurity (Lev. 15:4-27). 
Command the Israelites to send away from the camp anyone... who is ceremonially unclean because of a dead body (Num. 5:2); and

Whoever touches a human corpse will be unclean for seven days (Num. 19:11).

Various restrictions and purification requirements are applicable for such corpse related impurities. Persons and objects that are polluted remain impure for seven days and have to undergo several prescribed purification rituals:

They must purify themselves with the water on the third day and on the seventh day; then they will be clean. But if they do not purify themselves on the third and seventh days, they will not be clean... (Num. 19:12-19).

Related, but less serious than impurity contracted by touching a human a corpse, is that of coming into contact with certain dead animals, including most insects and all lizards (listed in Lev. 11:29-32). Restrictions and purifications for such contaminations are prescribed, but they are fewer than when touching a dead person. Lev. 11:24-25 states:

Whoever touches their carcasses will be unclean till evening. Whoever picks up one of their carcasses must wash their clothes, and they will be unclean till evening (also see Lev. 11:27-28, 39-40).

It is reasonable to assume that the Jews still observed purity regulations related to the touching of corpses in the time of Jesus. The parable of the Good Samaritan implies this as the priest and the Levite in the parable avoid contact beaten traveller (Lk. 10:25-37). Even in later rabbinic traditions (Rashi on b. Pesah, 14b, 17a; m. Kelim, 1:1-4; Tohar, 1:5) touching a corpse is called "the father of fathers of uncleanness" (Hayes, 2007:747). Although scholars generally suppose that these rabbinic writings date from a late stage, namely. 200 to 600 C.E. (Neusner, 1999:652), one has to keep in mind that the date of a document and the date of ideas taken up in it, stand some distance from one another. Ideas within the rabbinic literature most probably reflect ideas of some earlier stage in history.

To read of Jesus entering the room of a dead girl and taking her hand without hesitating, the first readers, who were mostly Jews, would expect Jesus to perform

2 The phrase "father of uncleanness" forms part of rabbinic terminology, which refers to impurity that can generate offspring of lesser impurities (Wright, 1992:730). 
the required purity rites. Yet, nothing in this regard is mentioned (Mt. 9:25)3. This would have raised questions and concern.

\subsection{Purity regulations related to sexual discharge}

The five "fathers of sexual impurities" are listed as seminal emission (Lev. 15:1618, 32), menstruation (Lev. 15:19-24; 18:19; 20:18), vaginal discharge after birth (Lev. 12), abnormal genital discharge of a male (Lev. 15:2-15; 22:4-6) and abnormal menstrual discharge (Lev. 15:25-30) (Hayes, 2007:747; Wright \& Jones, 1992:204207; Wright, 1992:731).

Semen-polluted persons cannot pollute other persons and things of the community, but are restricted from the holy sphere (Lev. 22:4-7). Impurity of menstruation is more serious as it can pollute others for seven days from the beginning of the blood flow. Persons or objects touching a woman with such bleeding become impure and persons touching something which she sat or laid on also become polluted: (Lev. 15:19-24). The impurity of vaginal discharge after birth is even more severe than menstruation. By giving birth to a child the regarded time of impurity is seven days after the birth of a boy and fourteen days after the birth of a girl (Lev. 12) and such a woman should be treated as a menstruant during this period (Lev. 12:2-5). The effect of pollution of a man with abnormal sexual discharge $(\boldsymbol{z a b})$ is similar to that of a menstruant. Once such a man is cured he can undergo purity rituals after seven days (Lev. 16:2-15). The female counterpart of a $z \boldsymbol{a} \boldsymbol{b}$ is that of a woman with abnormal menstrual discharge $(\boldsymbol{z a b a})$. Such a woman would pollute another person just as a man with abnormal genital discharge:

When a woman has a discharge of blood for many days at a time other than her monthly period or has a discharge that continues beyond her period, she will be unclean as long as she has the discharge, just as in the days of her period. Any bed she lies on while her discharge continues will be unclean, as is her bed during her monthly period, and anything she sits on will be unclean, as during her period. Anyone who touches them will be unclean; they must wash their clothes and bathe with water, and they will be unclean till evening (Lev. 15:25-30).

3 Mk. 5:41 and Luk. 8:54 also don't mention Jesus performing purification rites. However these evangelists don't put the same emphasis on Jesus' claim to observe the Law in its finest detail (Mt. 5:17-20). 
For Jesus not to be concerned when being touched by the woman with blood flow (Mark 5:25; Mt. 9:20; Luk. 8:34) ${ }^{4}$ would have been unusual for the readers of the first Gospel.

\subsection{Neglect of purification rites}

The delaying to purification after becoming impure is prohibited. The Hebrew Bible prescribes various purification rites such as bathing, laundering, sacrifices and in some cases even punishment to rectify such impurities. If the deed of becoming impure was avoidable and intentional it can result in the execution of the culprit (in cases of murder), karet (cutting off), or purification on the Day of Atonement (Wright, 1992:737-738).

The delay of purification after being polluted for touching human corpses, animal carcasses, and impure objects is considered as sinful and requires additional sacrifice and ablution (Chilton, 2000:874; Hayes, 2007:749):

If anyone becomes aware that they are guilty ... if they unwittingly touch anything ceremonially unclean (whether the carcass of an unclean animal, wild or domestic, or of any unclean creature that moves along the ground) and they are unaware that they have become unclean, but then they come to realize their guilt; or if they touch human uncleanness (anything that would make them unclean) even though they are unaware of it, but then they learn of it and realize their guilt; ... (Lev. 5:2-3).

Persons who advertently do not purify themselves will suffer being karet (cut off), or expelled:

...Everyone who does any of these detestable things, such persons must be cut off from their people... (Lev. 18:24-30) (see also Num. 19:13, 20).

In Jesus' cultural context, it would have been unacceptable for Him not to undergo purification rites after his contact with the bleeding woman or the dead girl.

Considering the above-mentioned regulations regarding purity, it seems as if Jesus did not observe these purity laws in a similar way as the Jews of his days. The question therefore arises of how this described behaviour of Jesus correlates with his explicit statement that his mission was not to abolish the Law or Prophets, but to fulfil them (Mt. 5:17-19). With this story Matthew apparently intends to advise his

4 Once again Mark 5:25 and Luk. 8:34 also don't mention Jesus performing purification rites, but Matthew writes to a predominantly Jewish audience and shows a specific interest in the maintenance of the details of the Law. 
readers of a specific interpretation of purity laws in terms of their relation to Jesus. With the coming of Jesus these laws got new meaning. This investigation can shed further light on what is implied by the statement by the Matthean Jesus that He came to fulfil the Law and the Prophets.

\section{JESUS' APPARENT NEGLECT OF PURITY REGULATIONS}

When observing the healings described in Mt. 9-10, it is important to recognize the textual context of the Law in which these stories are set.

\subsection{The teacher of the law enacts the law}

Once Matthew has ended the Sermon on the Mount, he continues to tell how Jesus came down from the mountain as Moses once did from Mount Sinai (Ex. 19:14; 32:1; 34:29). Matthew thus draws a parallel between Jesus and Moses, and the Mount of Jesus' sermon and Mount Sinai (Carter, 2000:198; Davies \& Allison, 2004a:9; Luz, 2001:5). The impressive and authoritative teacher of the Law of the discourse is presented in the subsequent narrative as going into action by demonstrating the meaning and correct practice of the Law. He confirms his authority by performing ten miracles. Grundmann fittingly describes the Sermon on the Mount as "das Wirken des Christus Jesus durch das Wort" (the work of Christ Jesus through the word) (Grundmann, 1971:111) and the miracles that follow as "das Wirken des Christus Jesus durch die Tat" (the work of Christ Jesus through the deed) (Grundmann, 1971:245).

The Sermon on the Mount and healing discourse are compositionally framed by two summaries of the miracles Jesus had performed (Morris, 1992:186; Senior, 1998:94; Talbert, 2010:109):

Jesus went throughout Galilee, teaching in their synagogues, proclaiming the good news of the kingdom, and healing every disease and sickness among the people... and people brought to him all who were ill with various diseases, those suffering severe pain, the demon-possessed, those having seizures, and the paralyzed; and he healed them (Mt. 4:23-25).

Sermon on the Mount (Mt. 5-7).

Healing narrative (Mt. 8-9). ${ }^{5}$

5 It is significant that the series of healing miracles includes one nature miracle, namely the stilling of the storm (Mt. 8:23-27). Matthew moves this nature miracle from the context as in Mark, and places it within a series of healing miracles (Mt. 8-9). After presenting Jesus as the Messiah of the Word in the Sermon on the Mount, Matthew 
Jesus went throughout Galilee, teaching in their synagogues, proclaiming the good news of the kingdom, and healing every disease and sickness among the people ... and people brought to him all who were ill with various diseases, those suffering severe pain, the demon-possessed, those having seizures, and the paralyzed; and he healed them (Matt 9:35).

In both these summaries reference is made to the Kingdom of heaven. With his inaugural proclamation "Repent, for the Kingdom of heaven is at hand" (Mt. 4:17), Jesus states that the future Kingdom of heaven is already present (Duling, 1992:57). The coming of the Kingdom is connected to the person of Jesus. The Kingdom does not only signify the territory where God rules, but also his activity as ruler as envisioned in Deutero-Isaiah (Davies \& Allison, 2004a:389). The Apocalypse of Baruch (2 Bar. 73:1-2) ${ }^{6}$ describes this anticipation:

And it shall come to pass, when He has brought low everything that is in the world and has sat down in peace for the age on the throne of His kingdom. That joy shall then be revealed and rest shall appear. And then healing shall descend in dew, and disease shall withdraw, and anxiety and anguish and lamentation pass from amongst men, and gladness proceeds through the whole earth.

continues to describe Jesus as the Messiah of the deed in the miracle narrative. The evangelist brings out a new motive by the context in which he places the miracle of the stilling of the storm. Before this miracle he places Jesus' teaching on the cost of following Jesus (Mt. 8:18-22) and afterwards Jesus' calling of Matthew to follow Him (Mt. 9:9-12) and the question why Jesus' disciples do not fast (Mt. 9: 14-17). Matthew interprets the journey of the disciples with Jesus in the storm and the stilling of the storm with reference to discipleship. The scope of the miracle is widened to become a description of discipleship and the church. When following Jesus, one can expect tribulation and rescue, and storm and security (Bornkamm, 1963:52-57). With the story of the stilling of the storm Matthew describes the challenges the church is confronted with. At the same time he uses the story to explain how Jesus subdues demonic powers and brings the $\beta \alpha \sigma i \lambda \varepsilon i \alpha$ (Kingdom) of God. By placing this miracle amongst the healing miracles, the healing miracles similarly become descriptions of the coming of God's Kingdom in a broken world.

6 Though 2 Baruch is attributed to the Biblical Baruch, it was probably written after the destruction of the Jerusalem in $70 \mathrm{AD}$ (Klijn, 1983:194), in the late first century or early in the second century. This document therefore reflects sentiments contemporary to Matthew. The document was most likely composed in Hebrew or Aramaic, but this original-language text did not survive. The only complete text of 2 Baruch is preserved in one Syriac manuscript (7a1). 
For Jesus the coming of the Kingdom did not comprise of one moment, but it realizes through a series of events over a period of time. When Jesus announces that the Kingdom of heaven has come and is coming, He indicates that the process of the realisation of God's rule has started, but the completion lies in the future, when the last things will come. The coming of the Kingdom is being established by Jesus. His teaching (Sermon on the Mount) and activity (healing miracles) form part of the realization of the blessings associated with the coming of the Kingdom. Purity regulations remind God's people of the devastating effect of sin and evil which destroys their relation with God, but with his miracles Jesus subdues these evil powers of sin and restores the relation between God and his people. With his purifying power He removes evil and establishes the Kingdom of heaven (Van der Walt, 2007:196).

\subsection{Double story of Jesus healing a woman with blood flow and a dead girl (Mt. 9:18-26)}

Mt. 9:18-34 presents the third triad of Matthew's miracle stories. ${ }^{7}$ These three short miracle stories include four miracles in which Jesus heals five people:

- The double story of the woman with blood flow and the ruler's ${ }^{8}$ daughter (Mt. 9:18-26);

- The story of two blind men (Mt. 9:27-31); and

- The story of a demoniac (Mt. 9:32-34).

These miracle stories demonstrate coming of God's Kingdom in anticipation of the wholeness expected in future.

The double story with which this triad of miracle stories begins, describes examples of how Jesus dealt with purity matters.

\subsubsection{Matthew's redaction of the story}

Matthew (Mt. 9:18-26) tells a much shorter version than Mk. (5:21-43) of the double story of Jesus healing the woman subject to bleeding for twelve years and of Him

7 Matthew tells a series of nine healing miracles stories (Mt. 8-9) and a nature miracle of Jesus stilling the storm (Mt. 8:23-27) in three triads. The nine healings are that of the leper, the centurion's servant, Peter's mother in law, the Gaderene demoniacs, the paralyzed man, the ruler's daughter, the woman with blood flow, the blind men and the dumb man.

8 In Matthew the ruler is unnamed, while both Mark and Luke call him Jairus. 
healing the dead girl of twelve ${ }^{9}$ years. Mark's priority is assumed. The redaction by Matthew should be considered in a comparison of these two versions.

\begin{tabular}{|c|c|}
\hline Mark 5:21-43 & Mt. 9:18-26 \\
\hline 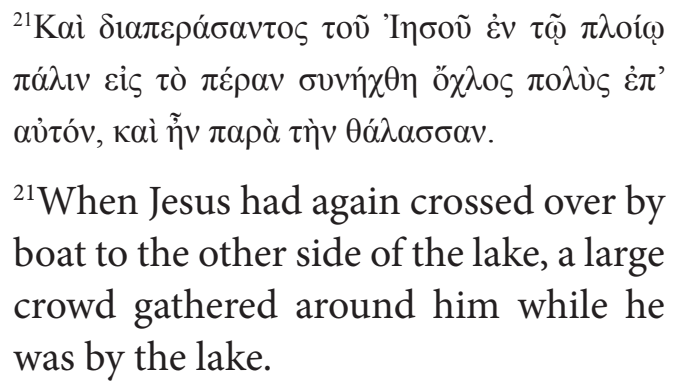 & 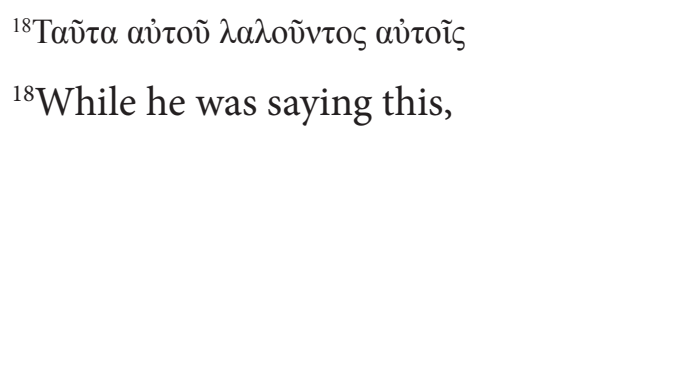 \\
\hline 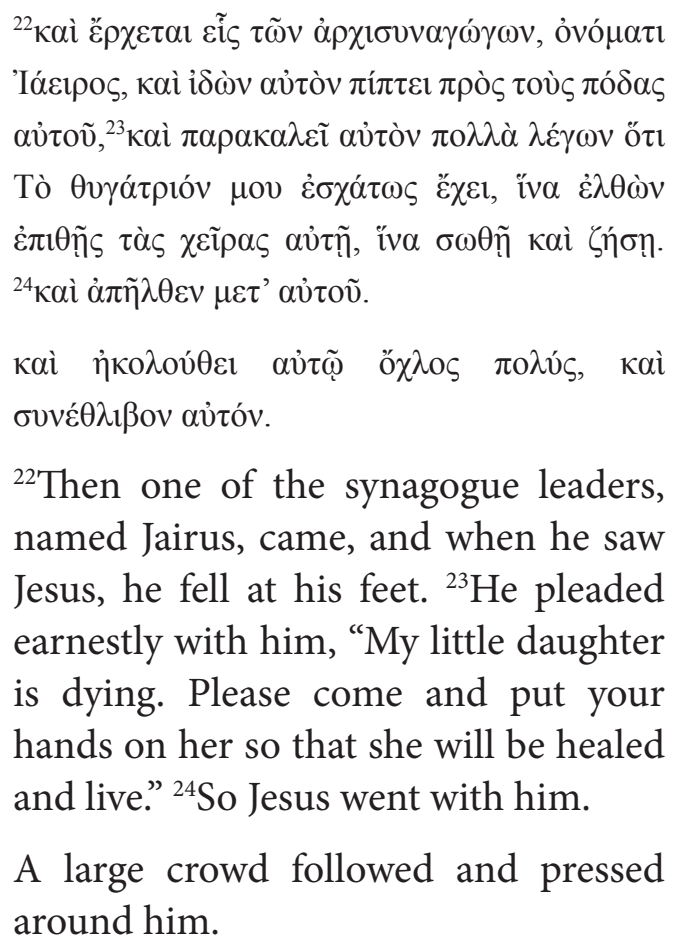 & 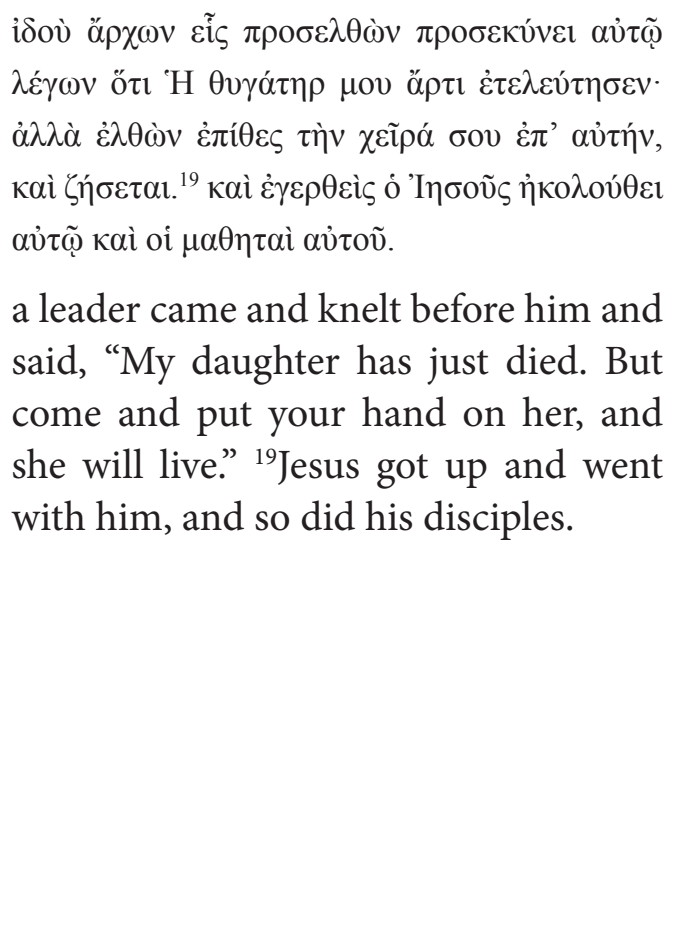 \\
\hline
\end{tabular}

9 The woman suffered bleeding over a period of twelve years, the same span of time as the age of the ruler's daughter. Menses also typically begins at the age of twelve. 


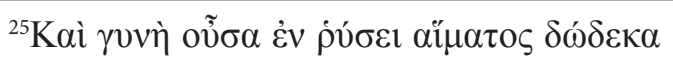

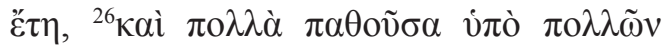

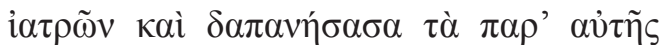

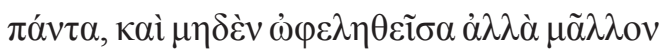

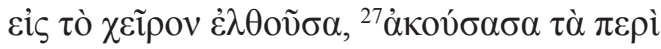

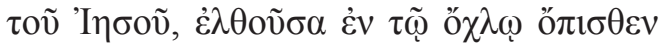

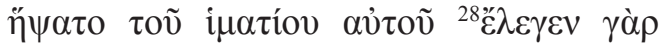

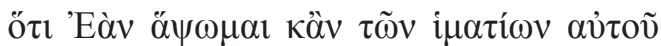

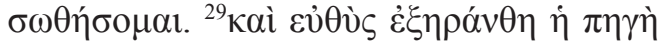

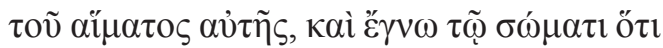

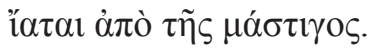

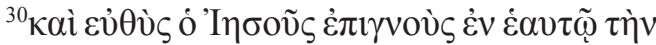

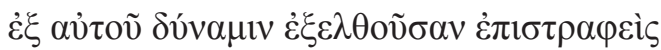

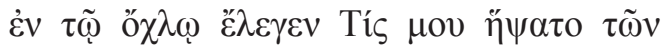
i $\mu \alpha \tau i ́ \omega v$;

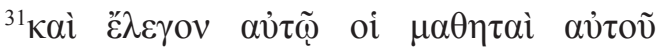

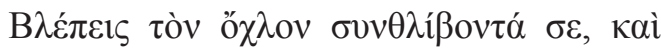

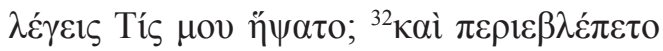

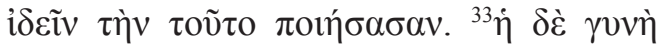

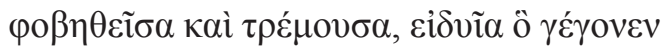

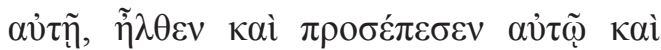

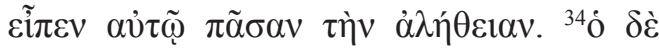

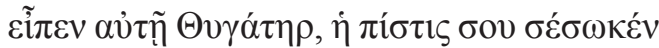

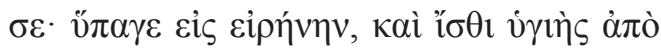
$\tau \tilde{\eta} \varsigma \mu \alpha ́ \sigma \tau \imath \gamma o ́ \varsigma \zeta \sigma o v$

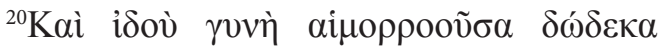

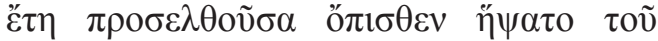

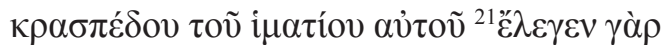

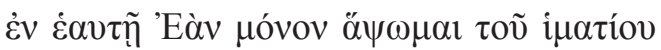
$\alpha$ $\tau$ õ $\sigma \omega \theta \eta ் \sigma o \mu \alpha$.

${ }^{22}$ ó $\delta \dot{\varepsilon}$ 'I

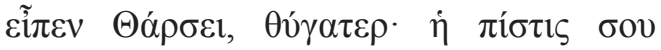

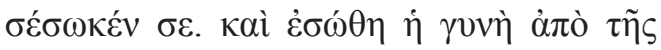

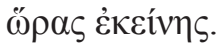

${ }^{20}$ Just then a woman who had been subject to bleeding for twelve years came up behind him and touched the edge of his cloak. ${ }^{21}$ She said to herself, "If I only touch his cloak, I will be healed."

${ }^{22}$ Jesus turned and saw her. "Take heart, daughter," he said, "your faith has healed you." And the woman was healed at that moment. 
${ }^{25} \mathrm{And}$ a woman was there who had been subject to bleeding for twelve years. ${ }^{26}$ She had suffered a great deal under the care of many doctors and had spent all she had, yet instead of getting better she grew worse. ${ }^{27}$ When she heard about Jesus, she came up behind him in the crowd and touched his cloak, ${ }^{28}$ because she thought, "If I just touch his clothes, I will be healed." ${ }^{29}$ Immediately her bleeding stopped and she felt in her body that she was freed from her suffering.

${ }^{30}$ At once Jesus realized that power had gone out from him. He turned around in the crowd and asked, "Who touched my clothes?"

31 "You see the people crowding against you," his disciples answered, "and yet you can ask, 'Who touched me?' "

${ }^{32} \mathrm{But}$ Jesus kept looking around to see who had done it. ${ }^{33}$ Then the woman, knowing what had happened to her, came and fell at his feet and, trembling with fear, told him the whole truth. ${ }^{34} \mathrm{He}$ said to her, "Daughter, your faith has healed you. Go in peace and be freed from your suffering." 


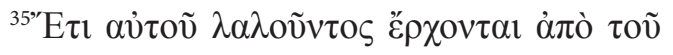

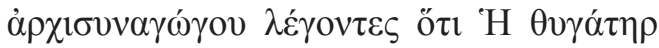

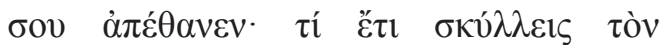
$\delta 1 \delta \alpha ́ \sigma \kappa \alpha \lambda \circ{ }^{\prime}$

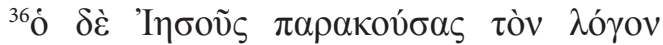

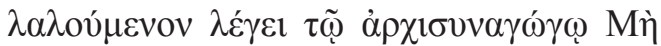


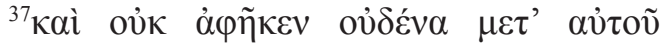

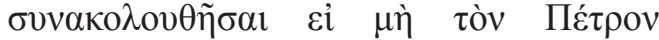

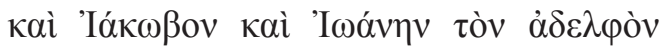

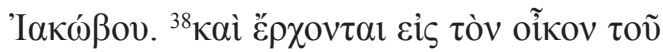

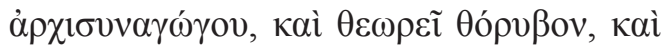

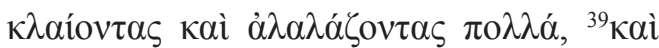

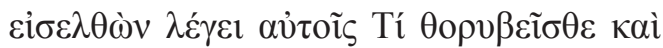

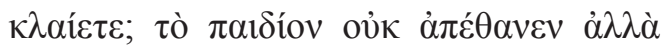

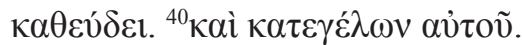

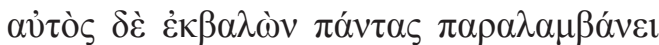

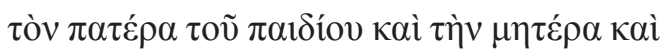

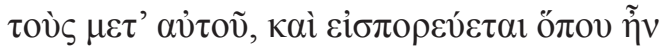

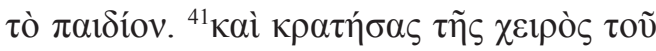

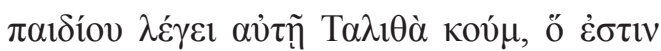

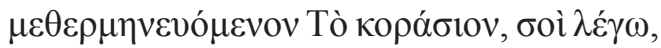

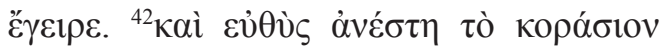

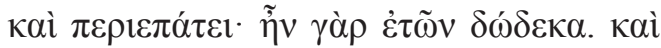

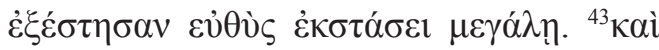

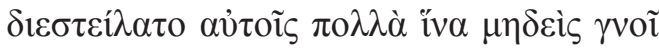

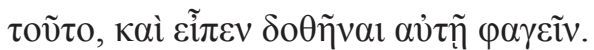

${ }^{35}$ While Jesus was still speaking, some people came from the house of Jairus, the synagogue leader. "Your daughter is dead," they said. "Why bother the teacher anymore?"

${ }^{36}$ Overhearing what they said, Jesus told him, "Don't be afraid; just believe."

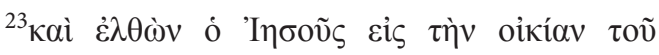

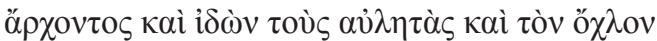

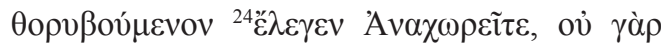

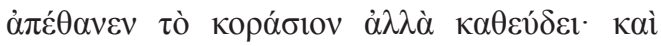

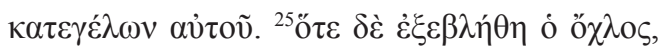

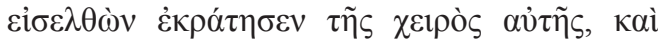

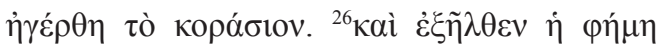

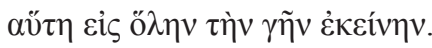

${ }^{23}$ When Jesus entered the synagogue leader's house and saw the noisy crowd and people playing pipes, ${ }^{24}$ he said, "Go away. The girl is not dead but asleep." But they laughed at him. ${ }^{25}$ After the crowd had been put outside, he went in and took the girl by the hand, and she got up. ${ }^{26}$ News of this spread through all that region. 
${ }^{37} \mathrm{He}$ did not let anyone follow him except Peter, James and John the brother of James. ${ }^{38}$ When they came to the home of the synagogue leader, Jesus saw a commotion, with people crying and wailing loudly. ${ }^{39} \mathrm{He}$ went in and said to them, "Why all this commotion and wailing? The child is not dead but asleep." ${ }^{40}$ But they laughed at him.

After he put them all out, he took the child's father and mother and the disciples who were with him, and went in where the child was. ${ }^{41} \mathrm{He}$ took her by the hand and said to her, "Talitha koum!" (which means "Little girl, I say to you, get up!"). ${ }^{42}$ Immediately the girl stood up and began to walk around (she was twelve years old). At this they were completely astonished. ${ }^{43} \mathrm{He}$ gave strict orders not to let anyone know about this, and told them to give her something to eat.

The most obvious difference is the much shortened version by Matthew, which is a general tendency with Matthew in his miracle stories. Matthew usually shortens Mark's narratives, especially the miracle stories, while he expands and inserts discourse material. Earlier scholars of the Synoptics were of the opinion that Matthew was careless in his abbreviations and weakened the narratives (Schniewind, 1930:139; Wellhausen, 1911:50). Yet Bornkamm (1963:52-57) demonstrates with his article on the stilling of the storm in Matthew that the evangelist exercises great care in his version of this miracle story. Matthew not only retells the story, but exegetes it. He applies the story of the stilling of the storm it to the trials and tribulations of discipleship and the church. Jesus rescues his disciples and people who believe in Him. He provides them security. Greeven (1955:69) indicates how Matthew abbreviates the story of the healing of the paralytic to reach the essentials of the story more quickly. Scholars became convinced that Matthew abbreviates the miracle stories for the sake of interpretation (Held, 1963:165-192). In comparison with Mark's version, Matthew cuts out a third of the first part of the story of the girl, two thirds of the 
woman with the blood flow and two thirds of the conclusion. Matthew makes no reference to the crossing of the lake (Mark 5:21), and it seems as if Jesus is still at table in the house (cf. Mt. 9:10). He neither mentions the crowds who followed and pressed against Jesus (Mk. 5:24). He omits details on how the haemorrhage woman suffered under the treatment of the doctors (Mk. 5:26) or about Jesus who turned around asking who touched Him (Mk. 5:30). Furthermore he twice omits reference to the disciples (Mark 5:31 and 37). He does not describe how the healed woman fell at the feet of Jesus trembling with fear (Mk. 5:33). Furthermore he does not mention the child's father and mother whom Jesus took with Him (Mk. 5:40). Similar to many other cases "Matthew seems impatient of Mark's asides and details and gives only the bare essentials of the story" (Hagner, 1993:246). It seems that Matthew abbreviates the story so that he can focus on the message he wants to convey with it. In Mt. 5:18-26 faith in Jesus and his healing power occupies the centre stage of the story.

A significant difference is that Mark 5:23 mentions that the daughter was dying and only after the healing of the haemorrhage women messengers announced her death (Mk. 5:35), but according to Mt. 9:25 she has died before her father first approached Jesus. In Matthew the ruler believes that Jesus can raise is daughter form death, while in Mark he expects that Jesus could save her from dying. While Mark refers

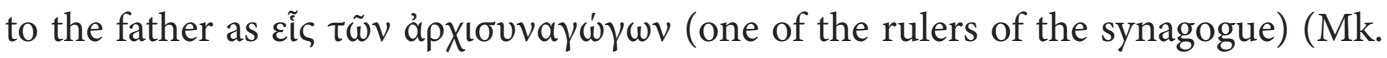
5:22), Matthew refers to him as ä $\rho \chi \omega v$ (a ruler) (Mt. 9:18). As is typical of Matthew, he once again omits any positive reference to the synagogue. The first Gospel throughout contrasts the hostile attitude of the synagogue and its leaders with the positive attitude of the church and its believing community. Matthew emphasises the

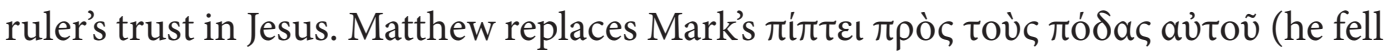

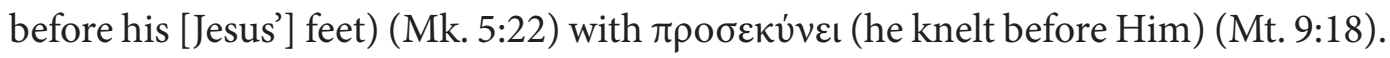
This verb describes the ruler prostrating before Jesus as his a superior in a gesture

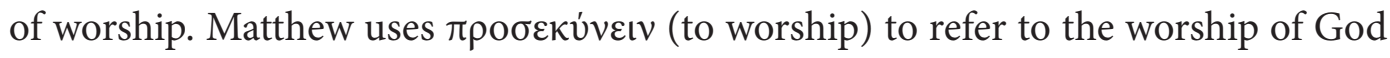
(Mt. 4:10) and to describe how people put their trust in Jesus and worship Him (Mt. 2:2, 8, 11; 8:2; 14:33; 15:25; 20:20 and 28:9, 17). Matthew clearly emphasises the ruler's faith in Jesus and his power to conquer death. Jesus also mentions the

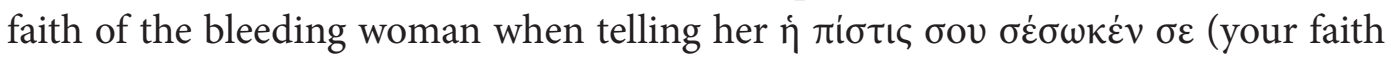
has healed you) (Mt. 9:22). As with the story of the stilling of the storm (Mt. 8:2327), the double story of Jesus healing these two women describes how Jesus rescues people from trouble and tribulation. Matthew also replaces the ó $\chi \lambda$ o $\varsigma$ ro $\lambda$ v́ (large

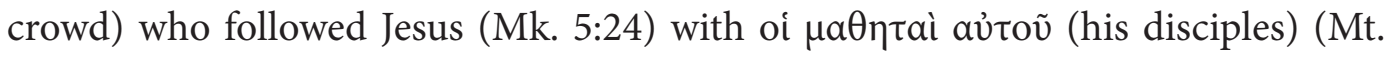
9:19). Matthew focuses on the faith community who witness and experience the restoring power of Jesus. 
As part of his interpretation Matthew also adds some detail in his retelling of miracle stories (Held, 1963:168). A significant addition by Matthew in this double story is that he mentions that Jesus wore a garment with tassels. The woman

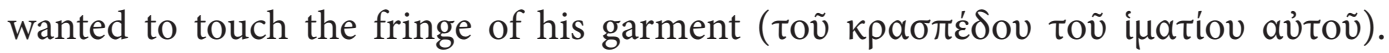
The fringe probably does not simply refer to the edge of Jesus' garment, but to the tassels (tzitzit) required by Num. 15:38-41 and Deut. 22:12. These tassels had to remind Jews to remain obedient to the Law (Carter, 2000:225; Hagner, 1993:249; Luz, 2001:42; Osborne, 2010:349). Matthew takes interest in Jesus' faithfulness to the Torah, even in his clothing. Furthermore Matthew replaces oũ $\sigma \alpha \dot{\varepsilon} v$ ṕv $\sigma \varepsilon l$ ailfatos (who had been subject to bleeding) (Mk. 5:25) with the rare compound

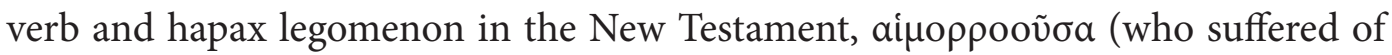
haemorrhage) (Mt. 9:20). This verb is also used in the LXX of Lev. 15:33, a passage in which sexual impurities and contamination are explained. Clearly Matthew wants to emphasise that Jesus was pious to the Torah, but nevertheless was not concerned by the touching of this woman. Later He would also touch the dead girl. Wainwright (1991:199) remarks: “... both (the woman and the girl) can be considered dead (one socially and religiously, the other physically), and both therefore have the capacity to contaminate life". Matthew emphasises, that even though these two females had the capacity to contaminate Jesus, Jesus in contrast had the power to heal them.

Matthew, as the other Synoptics, places the story of the bleeding woman as intercalation within the framework of the story of the raising of the young girl. In Matthew's version the sharp intercalation is marked with kaì i̇ov̀ (and then) (Mt. 9:20).

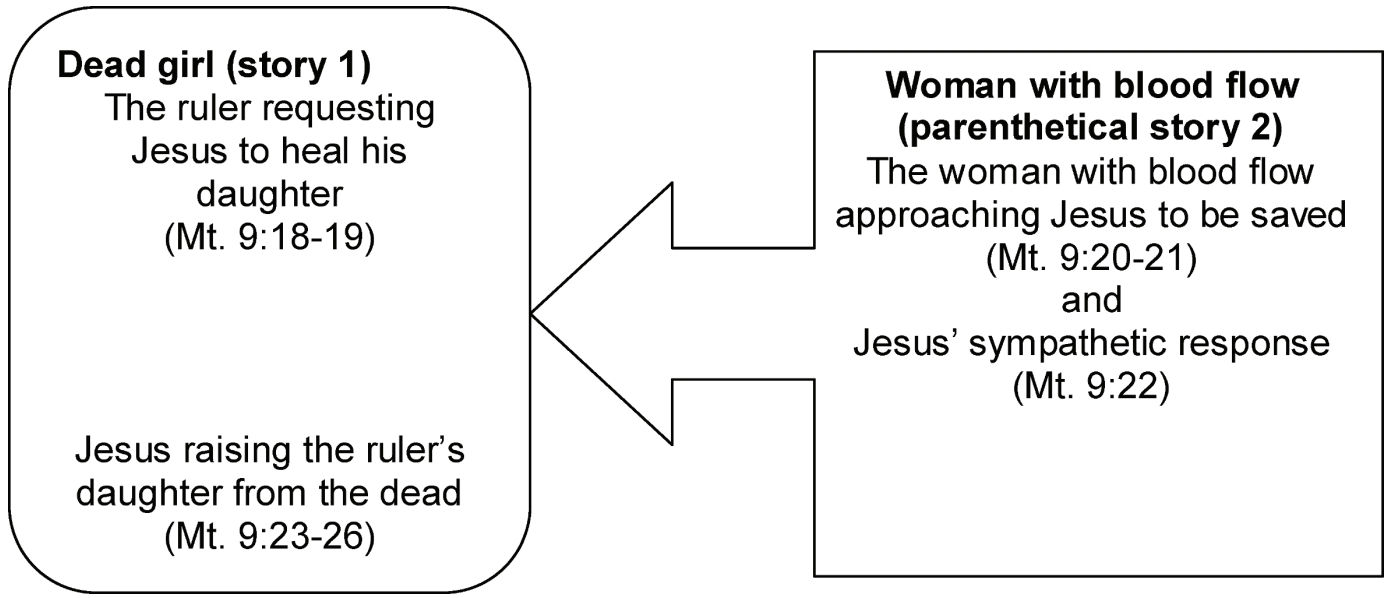

The technique of intercalation builds up suspense and highlights similarities between the stories (Carter, 2000:224; Osborne, 2010:347). Both stories vividly tell 
about faith. The faith of the ruler is tested by the intervening of the bleeding woman and Jesus commends the faith of the woman. Both stories tell about females in need, one twelve years of age and the other about a woman who suffered for twelve years. The one story is about a daughter, and the other about a woman whom Jesus calls daughter. Both tell about suffering, of the father and of the bleeding woman. In both stories touching is involved, the woman touching the fringe of Jesus' garment and Jesus taking the daughter by the hand. In both cases healing takes place. Both these healings are miracles. Both stories vividly describe hope in Jesus for people otherwise in hopeless situations. In both stories the people are powerless, but experience the power of Jesus. The one story tells about a direct approach and request, and the other about an indirect touching of Jesus. In both stories the focus is on Jesus. Faith is directed towards Him, He offers healing power and He brings wholeness and restoration.

Taking the cultural and textual context into consideration, it becomes clear that Matthew does not tell these stories for their own sake, but to tell something about the coming of the Kingdom, about faith and expectation, about the power and character of Jesus, about healing and access to Jesus. Purity regulations find new meaning through the teachings and healings of Jesus. With his healing power and care Jesus enacts the true intention of the Law.

\subsubsection{Jesus' reaction when touched by a woman with blood flow (Mt. 9:20-22)}

While Jesus was on his way to heal the daughter of the ruler who had just died, a woman who had been subject to bleeding for twelve years came up behind Him and touched the fringe of his cloak (Mt. 5:20). The interruption of this new story is marked by kaì íovì (and look). According to purity regulations her bleeding made her perpetually unclean, which caused constant social and religious separation (Lev. 15:25-30) (Anderson, 1983:11; Morris, 1992:229; Wainwright, 1994:648). "She was a virtual leper who would have had to leave family and village, lest contact with her renders everyone unclean" (Osborne, 2010:348). Even a touch from her would make someone unclean (Lev. 15:19 $\left.{ }^{10}\right)$. This includes a woman who's blood flow ${ }^{11}$ continues for a longer period (Lev 15:25 $5^{12}$ ). Also according to the Tannaim (Mishnah Zabim,

10 "When a woman has her regular flow of blood, the impurity of her monthly period will last seven days, and anyone who touches her will be unclean till evening" (Lev. 15:19).

11 Matthew uses the same word for blood flow as has been used in the LXX to Lev. 15:33, i.e.: aipoppoovion.

12 "When a woman has a discharge of blood for many days at a time other than her monthly period or has a discharge that continues beyond her period, she will be unclean as long as she has the discharge, just as in the days of her period" (Lev 15:25). 
$5.1,6)^{13}$, the impurity of a woman with blood flow can be transmitted through touching (Davies \& Allison, 2004b:128; Talbert, 2010:121). The woman in the story therefore took a risk to touch Jesus, which is probably the reason why she approached Him from behind (Luz, 2001:42; Morris, 1992:229; Witherington, 2006:203). This touching would leave Jesus ritually impure. Yet, when realising $\mathrm{He}$ was being touched, Jesus responds positively in a very sympathetic way. He turns to the woman and says to her: "Take heart, daughter ... your faith has healed you" (Mt. 9:22).

It is noteworthy to recognize the interaction between Jesus and the woman as illustrated in the following diagram.

\section{The woman (Mt. 9:20-21)}

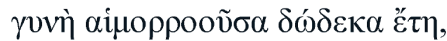

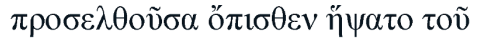

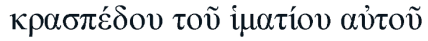
(a woman with blood flow for twelve years approaching from behind touched the fringe of his cloak).

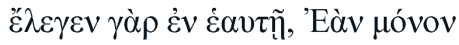

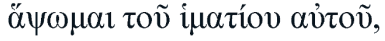
$\sigma \omega \theta \eta \dot{\sigma o \mu \alpha \imath}$

(she indeed said within herself, if only I shall touch his clothing, I will be saved).
Jesus (Mt. 9:22)
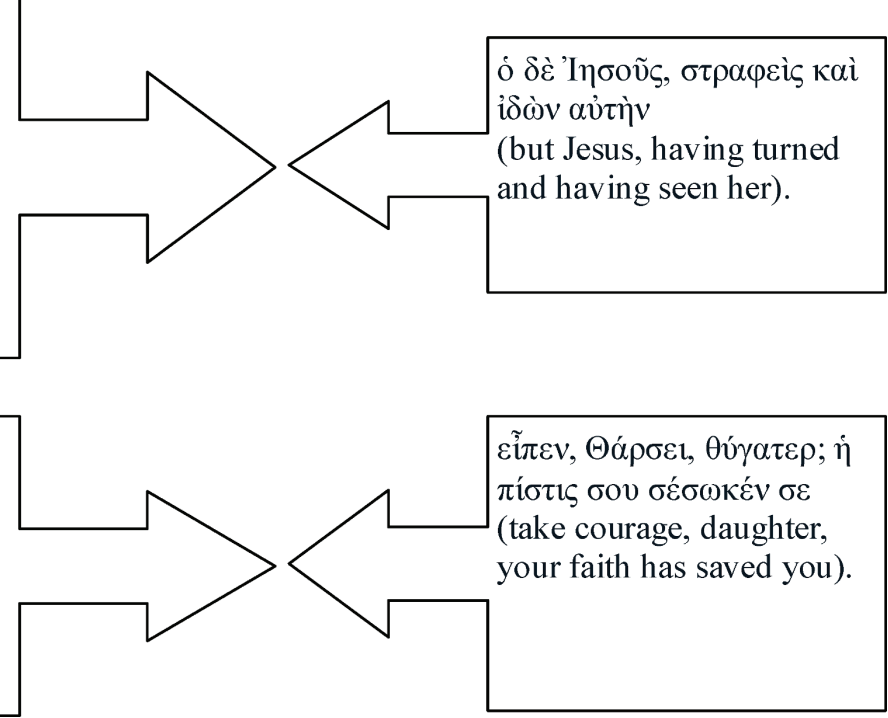

Matthew focuses on the interaction between the woman and Jesus alone. The vivid scene in Mk 5:25-26 of the seriousness of her sickness and how the woman tries to conceal herself in the crowd is omitted. Though presupposed, the crowd and

13 The Tannaim were Rabinnic sages who acted approximately from 10 to $220 \mathrm{CE}$. Their views were recorded in the Mishnah. The period of the Tannaim is also referred to as the Mishnaic period. Though the Mishnah was produced about 200 C.E. the ideas recorded in it, stem from an earlier period. The Mishnah therefore provides useful background information about the time of Jesus' ministry and the early church (Neusner, 1994:97). 
the disciples disappeared from the picture. No detail is given about the place, time or circumstances. In parallel style Matthew describes the interaction between the woman and Jesus. The initiative of the woman to approach Jesus from behind and to touch the fringe of his cloak, ${ }^{14}$ is paralleled by Jesus' turning around and seeing her. Her touching draws Jesus' attention. The woman is almost caught in her act, but Jesus turns to her sympathetically. Furthermore, the prayer like reasoning of the woman, "I will be saved" ( $\sigma \omega \theta \eta \dot{\sigma o} \mu \alpha) 15$, is paralleled by Jesus' positive response

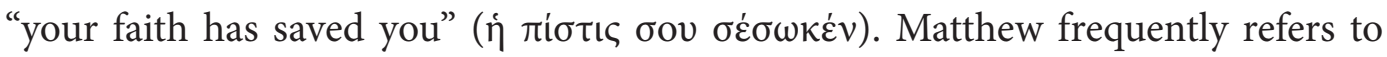
faith in the context of miracles (Mt. 8:13; 9:28, 15:28, 17:20 and 21:21). Faith implies trust in the power of Jesus to perform miracles ${ }^{16}$. The woman's expectation that Jesus could save her is comparable with a believer's prayer to God. She approaches Jesus in much the same way as one would approach God. As the Father knows the request of his children before they ask (Mt. 6:8), Jesus knows the need of this woman (Davies \& Allison, 2004b:129).

According to Jewish custom, one would expect Jesus to be upset for being defiled by the woman's action. Surprisingly Jesus responds with kindness as He knows both her faith and her plight. He encourages her to "take courage" and addresses her tenderly as "daughter". In comparison with Mark, Matthew omits that Jesus sensed that the power streamed out from Him, that He did not know who had touched Him and that the woman reacted fearfully when coming forward to confess that she did it (cf. Mk. 5:19-33).

The verbs that describe the woman's healing, both derivatives of save ( $\sigma \omega \zeta \varepsilon เ v)$, are significant. This alludes to the task of Jesus as stated in Mt. 1:21: "He will save his people from their sins". ${ }^{17}$ This is a statement with programmatic significance. It declares the messianic identity of Jesus, as well as what could be expected from Him to do (Novakovic, 2003:63-69). Jesus adds that her faith has saved her. Her bleeding and its consequent impurity disvalued her social status and she was excluded from society. To understand the impact of this desired healing, one has to consider what healing implied in the ancient Mediterranean world. Healing involved (at that time

14 The notion that healing could take place by touching a healer's clothing was common (cf. Acts 19:12) in those times (Davies \& Allison, 2004b:129).

15 It might be argued that the woman only expected Jesus to "save" her from her illness, but Matthew places her request firmly in context of faith.

16 Matthew places the double story alongside the healing of two blind men (Mt. 9:27-31) where the question about faith also plays a central role. All of these stories illustrate genuine faith in miracles.

17 Though the woman's faith could also refer to faith in God or in the Pharisaic robes, within this context is seems that she had faith in Jesus. 
and even today) more than physical healing from a disease. Healing implied the restoration of the total well-being of a person (Malina \& Rohrbauch, 2003:368; Pilch, 1988:60-66). This includes the restoration of meaning of life and honour. A healed person can fully participate in societal activities again. Healing, therefore, is culturally constructed. In this regard, one has to consider the difference between disease and illness. A disease causes sickness and is a pathological issue. Sickness exists irrespective of whether a culture recognizes it or not. Sickness is caused by viruses and germs. Illness, on the other hand, refers to misfortunes in well-being beyond a pathological state. An ill person is a socially disvalued person. Restoring the meaning of life for an ill person implies healing. The bleeding woman had the expectation and belief that Jesus could heal her from this deprived state. Jesus heals more than her physical ailment. Her whole person is healed and she can again fully participate in society.

Matthew's version intensifies the compassionate interaction between Jesus and the woman, with no hint of Jesus being upset for being touched by the unclean woman. Compassionate interaction forms a key component of the intention of the Law (Mt. 22:34-40). Mt. 9:20-22 describes the positive story in contrast to the suffering of the woman. She suffered not only because from the illness itself, but also from the purity restrictions. She is wholly presented in a positive light, no mention is made of her impurity, nothing is said about the fact that her touch would indignify Jesus, and onlookers do not mention anything about Jesus coming into contact with this unclean woman. Surely something different is at stake: "Instead of uncleanness passing from the woman to Jesus, healing power flows from Jesus to the woman" (Davies \& Allison, 2004b:130). In the ancient Mediterranean world, healers are considered to be holy men. Holy men have direct contact with the realm of God. The activity of holy men is supposed to benefit people of the society (Malina \& Rohrbauch, 2003:369). Jesus is identified as the Holy One, as the Holy Spirit came upon Him and is called the Son of God (Mt. 3:13-17). Jesus acts as Saviour and messianic Healer. He is Emmanuel, the Holy One. His healing forms part of the coming of the Kingdom of heaven. The purity regulations found their fulfilment in this act of Jesus who can bring an end to the ungodly power of impurity. He heals the woman by restoring her to her proper place in the community. Jesus is depicted as the miracle-working Saviour (Held, 1963:260). In Mt. 8:17 Matthew applies Is. 53:4 to Jesus. As servant of the Lord, He does away with the infirmities and sickness of this woman.

From this story it can be derived that the Matthew developed a new understanding of purity laws. As Jesus saves this woman from her distress, He saves his followers from their sins. He transposes purity for his followers from an external ritual to an 
internal ethical and moral level. This is probably intended in the sixth beatitude: "Blessed are the pure in heart" (Mt. 5:8).

\subsubsection{Jesus taking a dead girl by the hand (Mt. 9:25)}

This inserted story of Jesus' healing of the woman with blood flow is framed with the story of Jesus' raising the ruler's daughter from the dead.

Before this interruption, the father's request is reported. Unlike Mark, who wrote

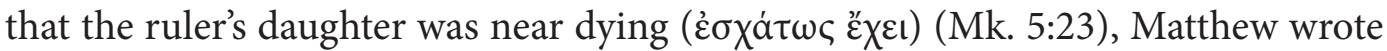

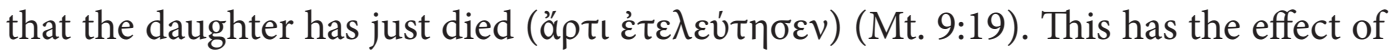
emphasising the faith of the ruler even in the face of death. He does not only believe that Jesus can heal his sick daughter, but that He can raise her from the dead. Right through the story he firmly and confidently trusts Jesus. This implies that the father's request that Jesus should lay his hand on her, would place Jesus in a state of impurity. Nevertheless, Jesus does not mention anything in this regard or hesitate to follow the ruler to his house.

After the interruption about the bleeding woman, the story continues with Jesus arriving at the house where the dead daughter was. Though Matthew limits the detail of the story, he does, however, add the references to the flute players and noisy crowd. These activities signify a funeral procession and emphasises the death of the girl (Hagner, 1993:250).

Matthew's version of the story is therefore, from the start right through to the end, about Jesus responding to the pleading of the father to raise his daughter from the dead. ${ }^{18}$ The flow of Matthew's carefully structured story can be demonstrated by the following diagram:

18 Levine (1996:394-396) notes the contrast between Jesus' constructive power with the destructive power of Herod who killed children (Mt. 2:16-18) and Herod Antipas who orders a killing because of a daughter (Mt. 14:1-12). 


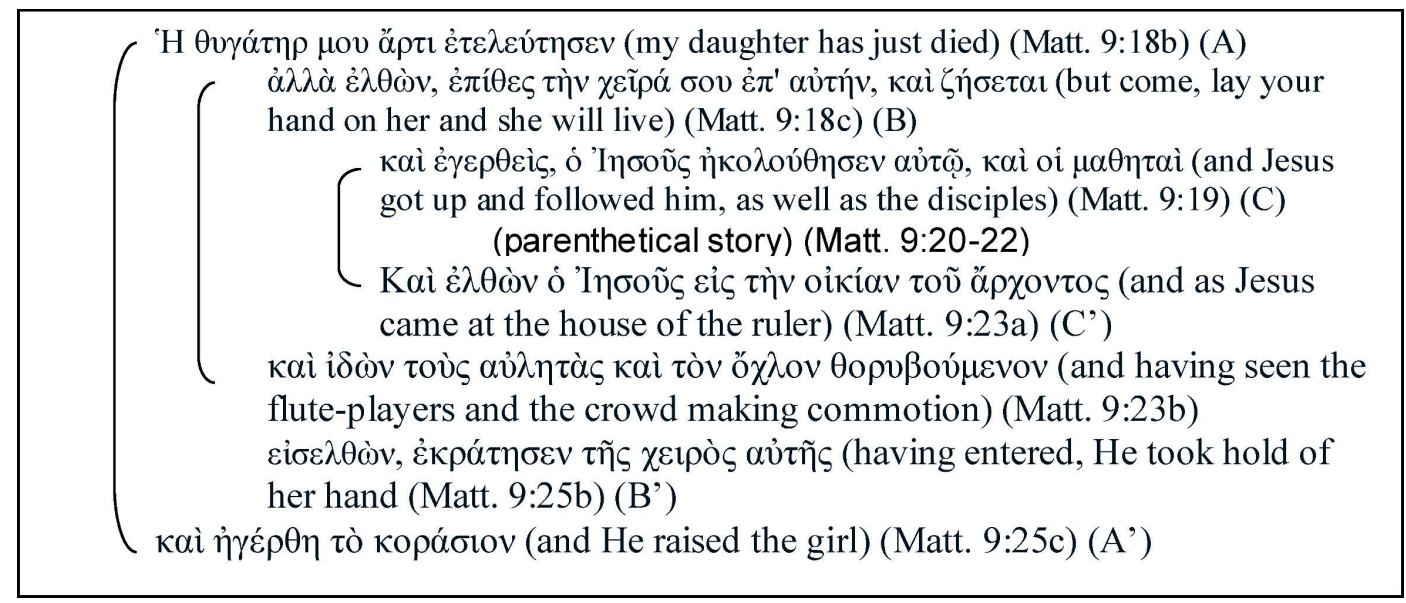

In this story the father states that his daughter has just died (Mt. 9:18b) which correlates with Jesus who raises her (Mt. 9:25c). This parallel accentuates the message that Jesus has the power to do much more that any human can. Similarly the father's request that Jesus should come and lay his hand on his daughter (Mt. 9:18c), is paralleled with Jesus entering the room and taking the girl by her hand (Mt. 9:25b). Matthew also refers to the hand of Jesus when healing a leper (Mt. 8:3). The hand of Jesus probably refers to the hand of Yahweh in the Hebrew Bible. The hand of Jesus can do what the powerful hand of Yahweh had done. The third parallel lies between Jesus and his disciples getting up and following the ruler (Mt. 9:19) and Jesus coming to the house of the ruler (Mt. 9:23a). Within this parallel structure Matthew's addition of the flute players and noisy crowds of the funeral procession is significant. This girl was dead indeed. Jesus does not hesitate to make contact with the dead girl, despite the fact that purity regulations state that this would leave Him impure.

The way Matthew describes Jesus' activity in the room, intensifies the private and close character of this miracle. After sending out the mourners, Jesus enters the room where the daughter is laying. Different from Mark, Matthew does not mention anything about the daughter's parents or his disciples (cf. Mark 5:37, 40). Having

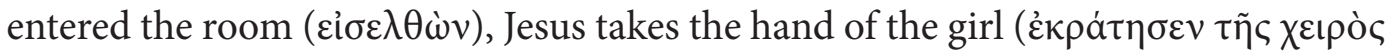
aủंñ ) (Mt. 9:25). Different from Mark (Mk. 5:41) or Luke (Lk. 8:54) who records that Jesus also spoke to the girl, Matthew only mentions Him taking her hand. Matthew explicitly mentions that Jesus takes the girl by the hand to raise her up (Luz, 2001:43; Witherington, 2006:203). Jesus' hand once again symbolizes his healing power (cf. Mt. 8:3, 15) (Hagner, 1993:250; Luz, 2001:41; Malina \& Rohrbauch, 2004:368). It is also significant how Matthew uses a series of three participles leading up to the two finite verbs to describe Jesus' actions at the house: The participles $\dot{\varepsilon} \lambda \theta \dot{\omega} v$ (coming) 
$+i \delta \grave{\omega} v$ (seeing) $+\varepsilon i \sigma \varepsilon \lambda \theta \dot{\omega} v$ (entering) intensify the expectation leading to the

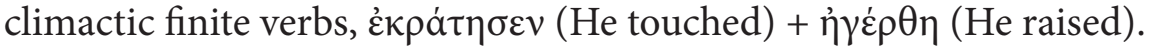

Apparently entering the room and touching the girl would leave Jesus ritually impure. Nevertheless Matthew makes no reference to Jesus hesitating to enter the room or to touch her. He actually intensifies the action with a series of participles leading up to the climactic finite action words. Matthew also does not make any reference to Jesus performing purification rituals after this deed. With this story, Matthew clearly relates a deeper message. While death is associated with impurity, Jesus does not become impure through this contact. The contrary happens. Life flows from Jesus to the girl to raise her from death. Death and its associated impurity are conquered. $\mathrm{He}$ is the healer and Holy One. Jesus has yet again brought the Kingdom of heaven a step closer. With his coming, the purity laws are fulfilled. Jesus enacts the intention of the Law.

\section{CONCLUSION}

The double story of Jesus healing the woman with blood flow and the daughter of the ruler describes a significant fulfilment of the purity laws of the Hebrew Bible. The Sermon on the Mount (Mt. 5-7) and the healing narrative (Mt. 8-9) are closely connected. While the Sermon on the Mount describes Jesus' teaching of the Law, the healing narrative describes his enactment of it. Thus the law provides the background for this story of Jesus, while the story of Jesus gives new meaning to the law. The purity laws form part of this.

Matthew's redactional intent becomes evident in the way he retells this double story. He does not merely tell it for its own sake, but for the message it contains. His descriptive parts are quite bare. He omits much of the pictorial details of Mark's story to concentrate on the messages he wishes to convey. His additions to Mark's version likewise show his special interests and intentions. The story demonstrates the nature of miracle faith in Jesus as the Servant of the Lord and Holy One who can cure these two women by touching them. Jesus is described as Emmanuel and the one who would save his people from their sins. As Saviour He purifies people, who believe in Him, of that which defiles them. As the Holy One, He touches people and purity flows from Him to them, while He Himself does not become impure. Doing this forms part of the coming of the Kingdom of heaven where eventually no impurity, sickness, illness and death will persist. Jesus thus has come to bring the purity laws to their fulfilment. 
Followers of Jesus share the healing and purifying power of Jesus. Within their faith community purity regulations are transformed from an external ritual to an internal moral level. Jesus expects from them to be pure at heart (Mt. 5:8).

\section{BIBLIOGRAPHY}

ANDERSON, J.C. 1983. Matthew: Gender and reading. Semeia, 28:3-27.

BORNKAMM, G. 1963. The stilling of the storm in Matthew. In G Bornkamm, G Barth and H.J. Held (eds.). Traditions and interpretation in Matthew, p. 52-57. London: SCM Press.

CARTER, W. 2000. Matthew and the margins. A Socio-Political and Religious reading. Sheffield: Academic Press (Journal for the Study of the New Testament Supplement series 204).

CHILTON, B.D. 2000. Purity. In C.A. Evans \& S.E. Porter (eds.). Dictionary of New Testament Background, p. 874-882. Downers Grove \& Leicester: Intervarsity Press.

DAVIES, W.D. \& ALLISON, D.C. 2004a. A Critical and exegetical commentary on the Gospel according to Saint Matthew. Volume 1 (Matthew 1-7). London \& New York: T \& T Clark International (International Critical Commentary).

DAVIES, W.D. \& ALLISON, D.C 2004b. A Critical and exegetical commentary on the Gospel according to Saint Matthew. Volume 2 (Matthew 8-18). London \& New York: T \& T Clark International (International Critical Commentary).

DEINES, R. 2008. Not the Law but the Messiah: Law and Righteousness in the Gospel of Matthew - an on-going debate. (In DM Gurtner \& J Nolland eds. Built upon the Rock. Studies in the Gospel of Matthew. pp.53-84. Grand Rapids \& Cambridge: Eerdmans).

DULING, D.C. 1992. Kingdom of God, Kingdom of heaven. (In D.N. Freedman (ed. in chief). The Anchor Bible Dictionary, volume 4, p. 56-69. New York, London, Toronto, Sydney \& Auckland: Doubleday).

GREEVEN, H. 1955. Die Heilung des Gelähmten nach Matthäus. In Wort und Dienst, Jahrbuch der Theologische Schule Bethel p. 61-75. Bethel: Theologische Schule. 
GRUNDMANN, W. 1971. Das Evangelium nach Matthäus. Theologischer Handkommentar zum Neuen Testament 1. Berlin: Evangelische Verlagsanstalt.

HAGNER, D.A. 1993. Matthew 1-13. Dallas: Word Books (Word Biblical Commentary 33A).

HAYES, C. 2007. Purity and impurity, ritual (In F. Skolnik \& M. Berenbaum (eds.). Encyclopaedia Judaica, second edition, volume 16, p. 746-756. Detroit, New York, San Francisco, New Haven, Waterville, Maine \& London: Thompson Gale).

HELD, H.J. 1962. Matthew as interpreter of the miracle stories. In G Bornkamm, G Barth and H.J. Held (eds.). Traditions and interpretation in Matthew, p. 165300. London: SCM Press.

KLIJN, A.F.J. 1983. 2 (Syriac Apocalypse of) Baruch, a new Translation and Introduction. In J. Charlesworth (ed.). The Old Testament Pseudepigrapha, Vol. 1, p. 193-199. New York: Double Day.

LEVINE, A.-J. 1996. Discharging responsibility: Matthean Jesus, Biblical Law and Haemorrhaging Woman( In D.R. Bauer \& M.A. Powell (eds.). Treasures New and Old: Contributions to Matthean studies. p. 379-397. SBL Symposium Series 1. Atlanta: Scholars Press).

MALINA, B.J. \& ROHRBAUCH, R.L. 2003. Social-science commentary on the Synoptic Gospels. Minneapolis: Fortress Press.

LUZ, U. 2001. Matthew 8-20, a commentary. Minneapolis: Fortress Press.

MORRIS, L. 1992. The Gospel according to Matthew. Grand Rapids \& Leicester: William Eerdmans.

NEUSNER, J. 19999. Introduction to rabbinic literature. New York: Doubleday.

NOVAKOVIC, L. 2003. Messiah, the healer of the sick. Tübingen: Mohr Siebeck. WUNT 2 Reihe 170.

OSBORNE, G.R. 2010. Matthew. Grand Rapids: Zondervan (Zondervan exegetical commentary on the New Testament).

PILCH, J.J. 1988. Understanding Biblical healing: selecting the appropriate model. Biblical Theological Bulletin, 18:60-66. 
SENIOR, D. 1998. Matthew. Nashville: Abingdon Press (Abingdon New Testament Commentaries).

SCHNIEWIND, J. 1930. Zur Synoptikerexegese. Theologische Rundschau, 2:135149.

TALBERT, C.H. 2010. Matthew. Grand Rapids: Baker Academic (Paideia commentaries on the New Testament).

VAN DER WALT, T. 2007. The Messiah has come. Potchefstroom: Potchefstroom Theological Publications.

VILJOEN, F.P. 2011. The foundational statement in Matthew 5:15-20 on the continuing validity of the Law. In die Skriflig (In Luce Verbi), 45 (2\&3):385-408.

VILJOEN, F.P. 2012. Interpreting the visio Dei in Matthew 5:8. Hervormde Teologiese Studies, 68(1): doi: 10.4102/hts.v68i1.905.

VILJOEN, F.P. 2013a. Righteousness and identity formation in the Sermon on the Mount. Hervormde Teologiese Studies, 69(1): doi: 10.4102/hts.v69i1.1300.

VILJOEN, F.P. 2013b. Jesus' halakhic argumentation on the true intention of the law in Matthew 5:21-48. Verbum et ecclesia, 34(1): doi: 10.4102/ve.v34i1.682.

VILJOEN, G.P. 2014a. Jesus healing the leper and the Purity Law in the Gospel of Matthew. In die Skriflig, 48(2), doi.org/10.4102/ids.v48i2.1751.

VILJOEN, F.P. 2014b. Hosea 6:6 and identity formation in Matthew. Acta Theologica.

VRIEZEN, T.C. \& VAN DER WOUDE, A.S. 2005. Ancient Israelite and early Jewish literature. Leiden \& Boston: Brill.

WAINWRIGHT, E.M. 1991. Towards a critical reading or the Gospel according to Matthew. New York: de Gruyter.

WAINWRIGHT, E.M. 1994. The Gospel of Matthew (In E.S. Fiorenza( ed.). Searching the Scriptures, volume 2. A Feminist commentrary. New York: Cross Road).

WELLHAUSEN, J. 1911]. Einleitung in die drei ersten Evangelien. Berlin: De Gruyter. 
WITHERINGTON, B. 2006. Matthew, Smyth \& Helwys Bible commentary, volume 19. Macon: Smyth \& Helwys Publishing.

WRIGHT, D.P. 1992. Unclean and clean (Old Testament) (In D.N. Freedman (ed. in chief). The Anchor Bible Dictionary, volume 5, p. 729-741. New York, London, Toronto, Sydney \& Auckland: Doubleday).

WRIGHT, D.P \& JONES, R.N. 1992. Discharge (In D.N. Freedman (ed. in chief). The Anchor Bible Dictionary, volume 2, p. 204-207. New York, London, Toronto, Sydney \& Auckland: Doubleday).

\section{KEY WORDS}

Purity laws

Holy / Holy One

Gospel of Matthew

Torah

Healing

Sick / Ill

Pure / impure

\section{TREFWOORDE}

Reinheidswette

Heilig / Die Heilige

Evangelie van Matteus

Torah

Genesing

Siek

Rein / onrein

\section{KONTAKBESONDERHEDE}

Prof. FP Viljoen

School for Biblical Studies and Ancient Languages

North-West University (Potchefstroom Campus)

E-mail: viljoen.francois@nwu.ac.za 
